\title{
DESIGN OF FUZZY LOGIC CONTROLLER FOR STARCH MODIFICATION PROCESS
}

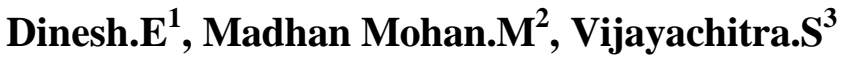 \\ ${ }^{I} P G$ Scholar, Electronics and Instrumentation Engineering, Kongu Engineering College, Tamil Nadu, India \\ ${ }^{2}$ Assistant Professor (Sr.G), Electronics and Instrumentation Engineering, Kongu Engineering College, Tamil Nadu, India \\ ${ }^{3}$ Professor, Electronics and Instrumentation Engineering, Kongu Engineering College, Tamil Nadu, India
}

\begin{abstract}
Starch is one of the utmost broadly circulated ingredients in flora, occurring in utmost plant life. Native starch from tapioca plant exhibits limited application due to low shear stress resistance, thermal decomposition, high viscosity, poor stability. To overcome the desirable functional properties and its limitations, native starches are modified by physical, chemical, enzymatic and genetic modifications. Presently in industries chemical modification method is most commonly used for starch modification process to meet the growing population demand of the developing countries. Currently chemical modification done through manual addition of different proposition of chemicals to the native starch obtained from the raw material according to the industrial standard requirements. Manual addition of chemicals is unsafe for food processing industry, time-consuming, require skilled operators and produce chemical by products. The proposed work involves design of fuzzy logic controller for oxidized modified starch manufacturing process with proper proposition mixing of the chemicals with the native starch according to the industrial standard requirements. Here fuzzy logic mamdani model was designed to extract the exact proposition of chemicals Sodium Hydroxide $(\mathrm{NaOH})$, Hydrochloric Acid $(\mathrm{HCl})$ and Sodium Hypochlorite $(\mathrm{NaClO})$ necessary to mix with native starch to manufacture oxidized starch. According to the variation of native starch properties as per the raw material available, the optimize level of chemical ratio to be added with the native starch for manufacturing process of oxidized starch is determined from fuzzy logic model with quality and safety measures.
\end{abstract}

Keywords: Starch Modification, Oxidized Starch, Fuzzy Logic Controller

\section{INTRODUCTION}

\subsection{Native Starch and Starch Modification}

Native Starch prepared from raw materials like potatoes, corn, wheat, tapioca etc., through several starch preparation steps like washing, rasping, extraction, refining and drying has low shear stress resistance, thermal decomposition, high viscosity, poor stability. In order to meet the growing population demand, it is necessary to convert the available native starch into modified starch. Starch Modification is the process of enriching the properties of native starch through physical, enzymatic, chemical modifications or combination of these methods to meet the demands of population growth rate through industrial production. Modified starches are used as raw material in various industries like paper industry, textile industry, construction industry, food industry, chemical industry, etc. The manufacturing of modified starches for various industries are named as oxidized starch, white dextrin starch, yellow dextrin starch, etc.

\subsection{Oxidized Starch}

Oxidized starch is one of the modified starches produced by reaction of native starch with oxidizing agent under controlled temperature and $\mathrm{pH}$. Several oxidizing agents have been used however, hypochlorite is the utmost mutual chemical used for manufacturing oxidized starch in an industrial scale. During the course of reaction, several reactions occur which lead to the introduction of carbonyl and carboxyl groups which degrade the starch molecules. Hence, oxidized starch exhibits low viscosity due to depolymerization and improve stability of starch dispersion.

\subsection{Oxidized Starch Preparation}

In industries, oxidized starch was prepared with the range of $\mathrm{pH}$ lies between 5.0 to 8.0 and viscosity lies between 1200 to 1800 centipoise minutes (cps min). According to Vedan Vietnam Enterprise Corp, Ltd QA Department, limit of sodium hydroxide and hydrochloric acid to be added with native starch must be less than $32 \%$ and for sodium hypochlorite it is less than $10 \%$. According to variation in the level of $\mathrm{pH}$ and viscosity of the native starch, the proper proportions of chemical reagents were added with the native starch in order to manufacture required modified starch. 


\subsection{Application of Oxidized Starch}

Oxidized starch is widely used in both food industries and nonfood industries where film development and adhesion properties are desired. It is also used in paper industries for improving quality of paper, mass and surface sizing. It provides yarn smoothing in textile industry and in construction industry for production of separation cardboard and acoustic strips.

\subsection{Proposed Method}

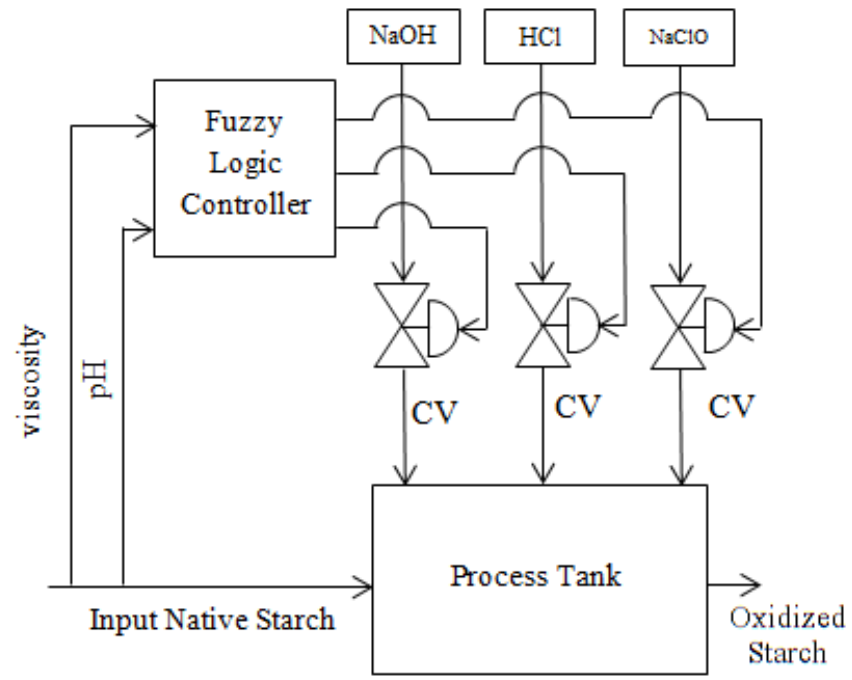

Fig -1: Block diagram of oxidized starch manufacture

Fig-1 shows the block diagram of manufacturing oxidized starch through chemical modification method. The $\mathrm{pH}$ and viscosity level of native starch act as input for the fuzzy logic controller. Fuzzy rules were created to open the control valve (CV) in proper proposition according to the knowledge of the starch modification process. The fuzzy logic controller controls the chemical proposition (sodium hydroxide, hydrochloric acid, and sodium hypochlorite) through control valve $(\mathrm{CV})$ opening according to the variation of $\mathrm{pH}$ and viscosity available in the native starch. Native starch and proper proposition of chemicals are mixed in the process tank as per the fuzzy rules framed for manufacturing oxidized starch.

\section{FUZZY LOGIC CONTROLLER}

Fuzzy logic, which is derived from Zadeh's theory of fuzzy sets and algorithms, offers an actual means of capturing the rough, inexact nature of the physical world. It can be used to convert a linguistic control policy based on skilled knowledge for automatic control policy to control a system in the absence of an exact mathematical model. The work defined here is to investigate the suitability of fuzzy technique for control the quality of modified starch. Here Mamdani method is used to convert the fuzzy value into crisp value i.e. fuzzification and centroid method is used for defuzzification.

\subsection{Fuzzy Input and Output Ranges}

The level of $\mathrm{pH}$ and viscosity available in the native starch act as input for fuzzy logic controller and it's range is mentioned in the table -1 . With respect to the table-1, $\mathrm{pH}$ range varies from acid high $(\mathrm{AH})$, acid low $(\mathrm{AL})$, neutral high $(\mathrm{NH})$, neutral medium (NM), neutral low (NL), base high (BH) and base low (BL). Similarly Viscosity range varies from extra high $(\mathrm{EH})$, very high $(\mathrm{VH})$, high $(\mathrm{H})$, medium $(\mathrm{M})$, low (L), very low (VL), extra low (EL). With respect to the table-2, the output range of sodium hydroxide, hydrochloric acid, and sodium hypochlorite range varies extra high $(\mathrm{EH})$, very high $(\mathrm{VH})$, high $(\mathrm{H})$, medium $(\mathrm{M})$, low (L), very low (VL), extra low (EL) .

Table -1: Fuzzy Input Ranges

\begin{tabular}{|c|c|c|c|}
\hline $\begin{array}{c}\text { Fuzzy } \\
\text { input } \\
\text { linguistic } \\
\text { variables }\end{array}$ & $\begin{array}{c}\mathrm{pH} \\
\text { Range } \\
(5-8)\end{array}$ & $\begin{array}{c}\text { Fuzzy input } \\
\text { linguistic } \\
\text { variables }\end{array}$ & $\begin{array}{c}\text { Viscosity } \\
\text { Range } \\
(1200-1800) \\
\text { cps minutes }\end{array}$ \\
\hline $\mathrm{AH}$ & $5.0-5.5$ & $\mathrm{EL}$ & $1200-1300$ \\
\hline $\mathrm{AL}$ & $5.0-6.0$ & $\mathrm{VL}$ & $1200-1400$ \\
\hline $\mathrm{NL}$ & $5.5-6.5$ & $\mathrm{~L}$ & $1300-1500$ \\
\hline $\mathrm{NM}$ & $6.0-7.0$ & $\mathrm{M}$ & $1400-1600$ \\
\hline $\mathrm{NH}$ & $6.5-7.5$ & $\mathrm{H}$ & $1500-1700$ \\
\hline $\mathrm{BL}$ & $7.0-8.0$ & $\mathrm{VH}$ & $1600-1800$ \\
\hline $\mathrm{BH}$ & $7.5-8.0$ & $\mathrm{EH}$ & $1700-1800$ \\
\hline
\end{tabular}

Table -2: Fuzzy Output Ranges

\begin{tabular}{|c|c|c|c|}
\hline $\begin{array}{c}\text { Fuzzy } \\
\text { output } \\
\text { linguistic } \\
\text { variables }\end{array}$ & $\begin{array}{c}\mathrm{NaOH} \\
\text { Range } \\
(0-20 \%)\end{array}$ & $\begin{array}{c}\mathrm{HCl} \\
\text { Range } \\
(0-20 \%)\end{array}$ & $\begin{array}{c}\text { NaClO } \\
\text { Range } \\
(0-10 \%)\end{array}$ \\
\hline EL & $0.0-0.5$ & $0.0-0.5$ & $0-1.66$ \\
\hline $\mathrm{VL}$ & $0.0-1.0$ & $0.0-1.0$ & $0-3.33$ \\
\hline $\mathrm{L}$ & $0.5-4.5$ & $0.5-4.5$ & $1.66-5$ \\
\hline
\end{tabular}




\begin{tabular}{|c|c|c|c|}
\hline $\mathrm{M}$ & $1.0-7.6$ & $1.0-7.6$ & $3.33-6.66$ \\
\hline $\mathrm{H}$ & $4.5-10.0$ & $4.5-10.0$ & $5-8.33$ \\
\hline $\mathrm{VH}$ & $7.6-20.0$ & $7.6-20.0$ & $6.66-10$ \\
\hline $\mathrm{EH}$ & $10.0-20.0$ & $10.0-20.0$ & $8.33-10$ \\
\hline
\end{tabular}

\section{FUZZY RULES}

As per the observation made in SPAC tapioca products (India) Ltd, punachi, Erode, it is necessary to manufacture the oxidized starch in the range of $\mathrm{pH} 5.0$ to 8.0 and viscosity 1200 to $1800 \mathrm{cps}$ min by including necessary chemical agents which lies between 0 to $20 \%$ for Sodium hydroxide and hydrochloric acid, whereas 0 to $10 \%$ for sodium hypochlorite. Forty nine rules were framed from the knowledge of the observed oxidized starch modification process and it is shown in table -3 .

Table -3: Fuzzy Rules

\begin{tabular}{|c|c|c|c|c|c|c|c|c|}
\hline \multirow{2}{*}{ 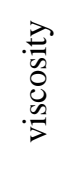 } & \multirow{2}{*}{ 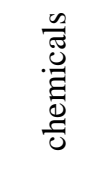 } & \multicolumn{7}{|c|}{$\mathrm{pH}$} \\
\hline & & $\begin{array}{l}\mathrm{A} \\
\mathrm{H}\end{array}$ & $\mathrm{AL}$ & $\mathrm{NL}$ & $\begin{array}{l}\mathrm{N} \\
\mathrm{M}\end{array}$ & $\begin{array}{l}\mathrm{N} \\
\mathrm{H}\end{array}$ & BL & $\mathrm{BH}$ \\
\hline \multirow{3}{*}{ EL } & $\begin{array}{l}\mathrm{NaO} \\
\mathrm{H} \\
\end{array}$ & $\mathrm{EH}$ & $\mathrm{H}$ & $\mathrm{L}$ & EL & $\mathrm{L}$ & EL & EL \\
\hline & $\mathrm{HCl}$ & EL & EL & $\mathrm{L}$ & EL & $\mathrm{L}$ & $\mathrm{H}$ & $\mathrm{EH}$ \\
\hline & $\begin{array}{l}\mathrm{NaCl} \\
\mathrm{O}\end{array}$ & EL & EL & EL & EL & EL & EL & EL \\
\hline \multirow{3}{*}{ VL } & $\begin{array}{l}\mathrm{NaO} \\
\mathrm{H}\end{array}$ & $\mathrm{EH}$ & $\mathrm{H}$ & $\mathrm{L}$ & EL & $\mathrm{L}$ & EL & EL \\
\hline & $\mathrm{HCl}$ & EL & EL & L & EL & L & $\mathrm{H}$ & $\mathrm{EH}$ \\
\hline & $\begin{array}{l}\mathrm{NaCl} \\
\mathrm{O}\end{array}$ & VL & VL & VL & VL & VL & VL & VL \\
\hline \multirow{3}{*}{$\mathrm{L}$} & $\begin{array}{l}\mathrm{NaO} \\
\mathrm{H}\end{array}$ & $\mathrm{EH}$ & $\mathrm{H}$ & $\mathrm{L}$ & EL & $\mathrm{L}$ & EL & EL \\
\hline & $\mathrm{HCl}$ & EL & EL & $\mathrm{L}$ & EL & $\mathrm{L}$ & $\mathrm{H}$ & $\mathrm{EH}$ \\
\hline & $\begin{array}{l}\mathrm{NaCl} \\
\mathrm{O}\end{array}$ & $\mathrm{L}$ & $\mathrm{L}$ & $\mathrm{L}$ & $\mathrm{L}$ & $\mathrm{L}$ & $\mathrm{L}$ & $\mathrm{L}$ \\
\hline \multirow{3}{*}{$\mathrm{M}$} & $\begin{array}{l}\mathrm{NaO} \\
\mathrm{H} \\
\end{array}$ & $\mathrm{EH}$ & $\mathrm{H}$ & $\mathrm{L}$ & EL & $\mathrm{L}$ & EL & EL \\
\hline & $\mathrm{HCl}$ & EL & EL & $\mathrm{L}$ & EL & $\mathrm{L}$ & $\mathrm{H}$ & $\mathrm{EH}$ \\
\hline & $\begin{array}{l}\mathrm{NaCl} \\
\mathrm{O}\end{array}$ & $\mathrm{M}$ & $\mathrm{M}$ & $\mathrm{M}$ & $\mathrm{M}$ & M & $\mathrm{M}$ & $\mathrm{M}$ \\
\hline \multirow{3}{*}{$\mathrm{H}$} & $\begin{array}{l}\mathrm{NaO} \\
\mathrm{H}\end{array}$ & EH & $\mathrm{H}$ & $\mathrm{L}$ & EL & $\mathrm{L}$ & EL & EL \\
\hline & $\mathrm{HCl}$ & EL & EL & $\mathrm{L}$ & EL & $\mathrm{L}$ & $\mathrm{H}$ & $\mathrm{EH}$ \\
\hline & $\begin{array}{l}\mathrm{NaCl} \\
\mathrm{O}\end{array}$ & $\mathrm{H}$ & $\mathrm{H}$ & $\mathrm{H}$ & $\mathrm{H}$ & $\mathrm{H}$ & $\mathrm{H}$ & $\mathrm{H}$ \\
\hline
\end{tabular}

\begin{tabular}{|c|c|c|c|c|c|c|c|c|}
\hline \multirow{3}{*}{$\mathrm{VH}$} & $\begin{array}{l}\mathrm{NaO} \\
\mathrm{H} \\
\end{array}$ & EH & $\mathrm{H}$ & $\mathrm{L}$ & EL & $\mathrm{L}$ & EL & EL \\
\hline & $\mathrm{HCl}$ & EL & EL & $\mathrm{L}$ & EL & $\mathrm{L}$ & $\mathrm{H}$ & $\mathrm{EH}$ \\
\hline & $\begin{array}{l}\mathrm{NaCl} \\
\mathrm{O}\end{array}$ & $\begin{array}{l}\mathrm{V} \\
\mathrm{H}\end{array}$ & $\begin{array}{l}\mathrm{V} \\
\mathrm{H}\end{array}$ & $\begin{array}{l}\mathrm{V} \\
\mathrm{H} \\
\end{array}$ & $\begin{array}{l}\mathrm{V} \\
\mathrm{H}\end{array}$ & $\begin{array}{l}\mathrm{V} \\
\mathrm{H} \\
\end{array}$ & $\begin{array}{l}\mathrm{V} \\
\mathrm{H}\end{array}$ & $\mathrm{VH}$ \\
\hline \multirow{3}{*}{$\mathrm{EH}$} & $\begin{array}{l}\mathrm{NaO} \\
\mathrm{H} \\
\end{array}$ & $\mathrm{EH}$ & $\mathrm{H}$ & $\mathrm{L}$ & EL & $\mathrm{L}$ & EL & EL \\
\hline & $\mathrm{HCl}$ & EL & EL & L & EL & L & $\mathrm{H}$ & $\mathrm{EH}$ \\
\hline & $\begin{array}{l}\mathrm{NaCl} \\
\mathrm{O}\end{array}$ & $\mathrm{EH}$ & EH & $\mathrm{EH}$ & EH & EH & EH & $\mathrm{EH}$ \\
\hline
\end{tabular}

\section{RESULTS AND DISCUSSIONS}

The input native starch range received from the raw materials and necessary oxidized starch range for manufacturing process are shown in table 4 . To modify the native starch into required oxidized starch, $\mathrm{NaClO}$ used to maintain the viscosity whereas a combination of $\mathrm{HCl}$ and $\mathrm{NaOH}$ used to maintain the $\mathrm{pH}$ level. According to Fig-2, when the value of $\mathrm{pH}$ and viscosity of native starch were 5.341 and 1251 respectively, then the required chemical proposition for oxidized starch manufacturing process were $\mathrm{NaOH}=14.5 \%, \mathrm{HCl}=0.124 \%$ and $\mathrm{NaClO}=1.45 \%$. As per Fig-3, when the value of $\mathrm{pH}$ and viscosity of native starch were 6.48 and 1482 respectively, then the required chemical proposition for oxidized starch manufacturing process were $\mathrm{NaOH}=1.07 \%, \mathrm{HCl}=1.07 \%$ and $\mathrm{NaClO}=4.63 \%$. As per Fig-4, when the value of $\mathrm{pH}$ and viscosity of native starch were 7.2 and 1620 respectively, then the required chemical proposition for oxidized starch manufacturing process were $\mathrm{NaOH}=2.28 \%, \mathrm{HCl}=5.73 \%$ and $\mathrm{NaClO}=7.11 \%$.

Table -4 Input Native Starch Range and Required Output Starch Range

\begin{tabular}{|c|c|c|}
\hline Type & $\mathrm{pH}$ & Viscosity(cps min) \\
\hline $\begin{array}{c}\text { Input Native } \\
\text { Starch }\end{array}$ & $5.0-8.0$ & 1500 \\
\hline $\begin{array}{c}\text { Output } \\
\text { Oxidized } \\
\text { Starch }\end{array}$ & $6.0-7.0$ & $70-100$ \\
\hline
\end{tabular}

Table -5 Required chemicals for variation of $\mathrm{pH}$ and viscosity available in native starch

\begin{tabular}{|c|c|c|c|c|}
\hline \multicolumn{2}{|c|}{ Native starch } & \multicolumn{3}{|c|}{$\begin{array}{c}\text { Proposition of chemicals required } \\
\text { for oxidized starch modification } \\
\text { process }\end{array}$} \\
\hline $\mathrm{pH}$ & viscosity & $\begin{array}{c}\mathrm{NaOH} \\
(\%)\end{array}$ & $\begin{array}{c}\mathrm{HCL} \\
(\%)\end{array}$ & $\begin{array}{c}\mathrm{NaClO} \\
(\%)\end{array}$ \\
\hline 5.341 & 1251 & 14.5 & 0.179 & 1.45 \\
\hline
\end{tabular}




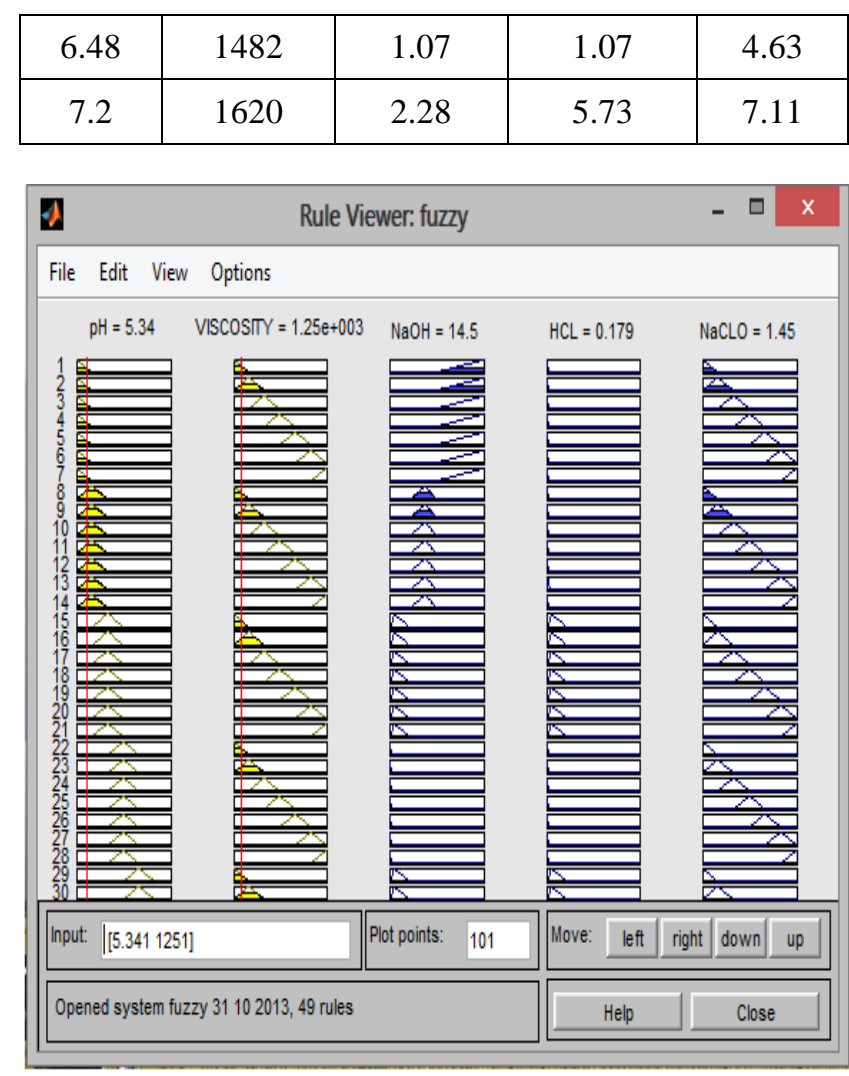

Fig -2: Rule Viewer of output 1

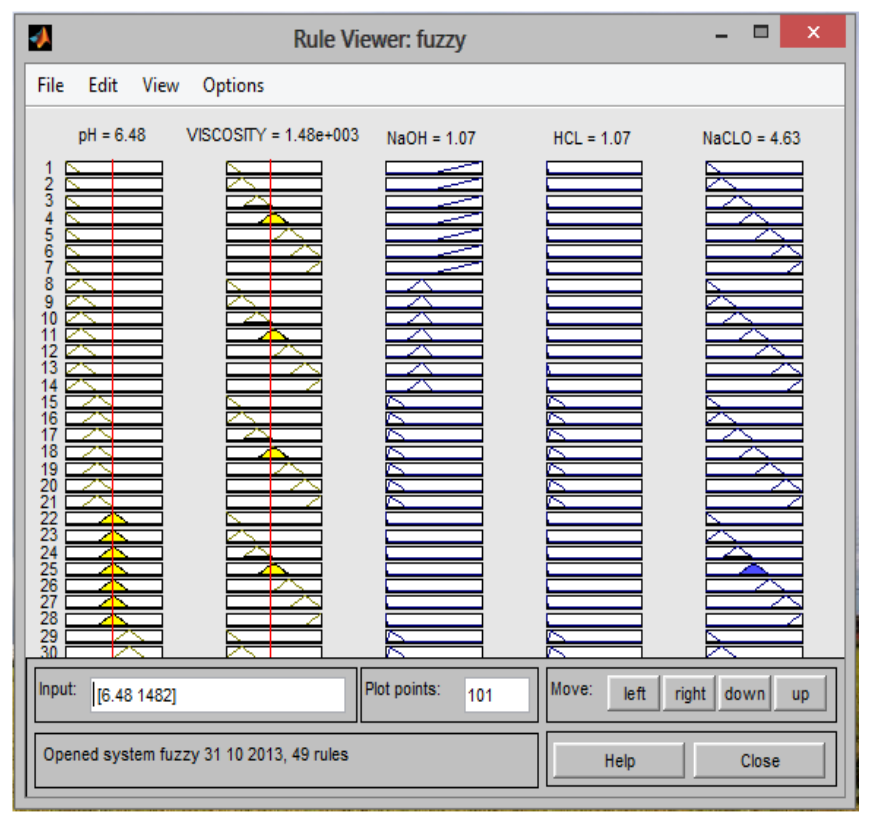

Fig -3: Rule Viewer of output 2

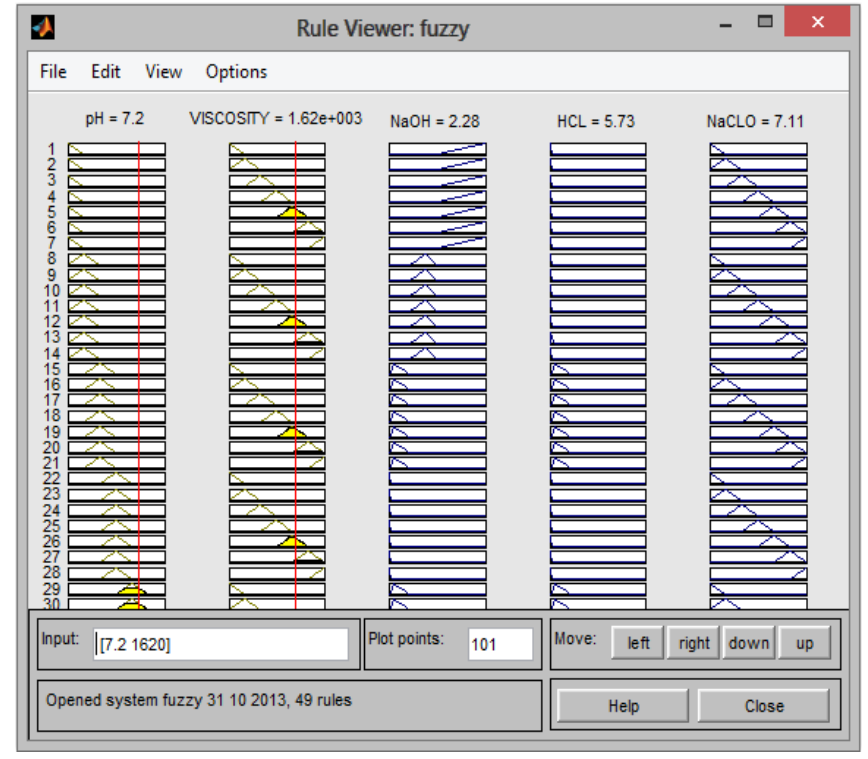

Fig -4: Rule Viewer of output 3

\section{CONCLUSIONS}

Today the prediction of optimized range of chemical mixing proposition is an essential issue to keep the chemical proposition under safer limits to avoid health and environmental problems in food and other industries. The proposed fuzzy logic controller predicts the accurate proposition of chemicals necessary to mix with the native starch to manufacture the modified starch (oxidized starch) with quality and safety measures. The designed fuzzy logic model for oxidized starch manufacturing process using mamdani method predict the proper proposition of Hydrochloric acid, Sodium Hydroxide, Sodium Hypochlorite to be added with the native starch. Fuzzy logic controllers does not need mathematical model and only need few rules, suitable membership function according to the knowledge of the process. In future this work can be extended for designing fuzzy logic controller for multiple modified starch production.

\section{ACKNOWLEDGMENTS}

The authors wish to express our special thanks to SPAC Tapioca Product Pvt Ltd for their support extended for us.

\section{REFERENCES}

[1] Akpa, Jackson Gunorubon and Dagde, Kenneth Kekpugile (2012) 'Modification of Cassava Starch for Industrial Uses' International Journal of Engineering and Technology volume. 2 no.6 pp.913-919

[2] Akpa Jackson Gunorubon (2012) 'Production of cassava starch-based adhesive' Research Journal in Engineering and Applied Sciences volume.1 no.4 pp. 219-224 
[3] Juan Chen Yawei Peng Weisha Hana Min Guo (2011) 'Adaptive fuzzy sliding mode control in $\mathrm{PH}$ neutralization process' Procedia Engineering 15 pp.954 $-958$

[4] Kunruedee Sangseethonga, Niti Termvejsayanona, Klanarong Srirothb (2010) 'Characterization of physicochemical properties of hypochlorite and peroxide-oxidized cassava starches' Carbohydrate Polymers 82 pp.446-453

[5] Lucia Helena Garrido, Egon Schnitzler, Manoela Estefanea Boff Zortea, Thais de Souza Rocha, Ivo Mottin Demiate (2012) 'Physicochemical properties of cassava starch oxidized by sodium hypochlorite' Journal of Food Science and Technology 13197-0120794-9

[6] Magan. P. Ghatule (2013) 'Design and Development of pH Neutralization Process a Fuzzy Logic Based Electronics Sensing and Control System' International Journal of Engineering Research \& Technology (IJERT) Vol. 2 ISSN: 2278-0181

[7] Mahsa Majzoobi1, Mohsen Radi1, Asgar Farahnaky1, Jalal Jamalian1 and Taewee Tongdang (2009) 'Physico-chemical Properties of Phosphoryl Chloride Cross-linked Wheat Starch' Iranian Polymer Journal18(6), 491-499

[8] Michael Riis Hansen, Andreas Blennow , Sven Pedersen , Soren B. Engelsen (2009) 'Enzyme modification of starch with amylomaltase results in increasing gel melting point' Carbohydrate Polymers pp. $72-79$

[9] K.A. Abbas, Sahar K. Khalil, Anis Shobirin Meor Hussin (2010) 'Modified Starches and Their Usages in Selected Food Products: A Review Study' Journal of Agricultural Science ISSN: 1916-9752 Vol. 2.

[10] Rachtanapun, P, Simasatitkul, P, Chaiwan, W and Watthanaworasakun, Y (2012) 'Effect of sodium hydroxide concentration on properties of carboxymethyl rice starch' International Food Research Journal 19 (3): 923-931

[11] Singh I, Sharma V, Sharma S (2011) 'Preparation and characterization of modified starch isolated from amaranthu spaniculatuslinn' international journal of current pharmaceutical research vol 3, issue 2

[12] Kunruedee Sangseethong, Sirithorn Lertpanit, and Klanarong Sriroth,(2005) 'Hypochlorite oxidation of cassava starch' Bangkok (Thailand)

\section{BIOGRAPHIES}

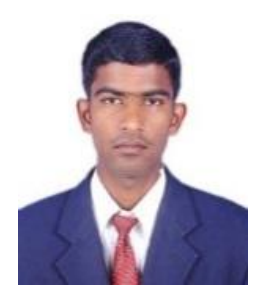

E.Dinesh has received B.E (Electrical and Electronics Engineering) degree from Anna University Chennai in the year 2012.He is currently pursuing M.E (Control and Instrumentation Engineering) at Kongu Engineering College, Perundurai-638 052, India.. His area of interest includes Control
Systems, and Power System.

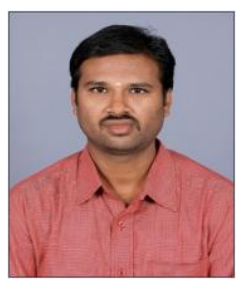

Mr.M.Madhan Mohan has received his UG degree (Electrical and Electronics Engineering) from Madurai Kamaraj University and PG Degree (VLSI Design) from Anna University of Technology, Coimbatore in the year 2004 and 2010 respectively. Currently he is serving as Assistant Professor (Senior Grade) in the Department of Electronics and Instrumentation Engineering at Kongu Engineering College, Perundurai-638 052, India. His areas of interest are microprocessor and microcontroller, embedded systems, MEMS. Now he is working in the area of Quality Determination.

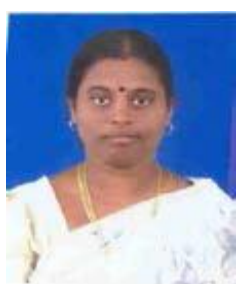

Dr.S.Vijayachitra has received her PG degree (Process Control \& Instrumentation Engineering) from Annamalai University and $\mathrm{PhD}$ Degree (Electrical Engineering) from Anna University Chennai in the year 2001 and 2009 respectively. Currently she is serving as Professor in the Department of Electronics and Instrumentation Engineering at Kongu Engineering College, Perundurai-638 052 India. She published more than 30 research papers in various International Journals and Conference Proceedings. She also published three books on "Industrial Instrumentation" at New Age International Publishers, New Delhi. Her area of interest includes Neural Networks, Fuzzy Logic, Genetic Algorithms, Process Modeling and etc. 